\title{
Edging Toward 'Reasonably' Good Corporate Governance
}

\author{
Donald Nordberg $^{1}$ (D)
}

Published online: 5 February 2018

(C) The Author(s) 2017. This article is an open access publication

\begin{abstract}
Over four decades, research and policy have created layers of understandings in the quest for "good" corporate governance. The corporate excesses of the 1970s sparked a search for market mechanisms and disclosure to empower shareholders. The UK-focused problems of the 1990s prompted board-centric, structural approaches, while the fall of Enron and many other companies in the early 2000s heightened emphasis on director independence and professionalism. With the financial crisis of 2007-09, however, came a turn in some policy approaches and in academic literature seeking a different way forward. This paper explores those four phases and the discourse each develops and then links each to assumptions about accountability and cognition. After the financial crisis came pointers $\mathrm{n}$ policy and practice away from narrow, rationalist prescriptions and toward what the philosopher Stephen Toulmin calls "reasonableness". Acknowledging that heightens awareness of complexity and interdependence in corporate governance practice. The paper then articulates a research agenda concerning what "reasonably" good corporate governance might entail.
\end{abstract}

Keywords Corporate governance $\cdot$ Boards of directors $\cdot$ Investors $\cdot$ Rationality $\cdot$ Reasonableness

\section{Introduction}

Four decades have passed since the seminal paper by Jensen and Meckling (1976) established the field we know as corporate governance. A quarter of a century has passed since Cadbury (1992) published the report and code that became the benchmark for the field, in Britain and many countries around the world. The explosion of research and policymaking that took developed during that period has provided a wealth of insights about boards of directors, institutional investors, and the roles that codes of conduct, corporate disclosure and transparency play in the functioning of equity capital markets and strategic leadership. Practice has changed, too. Boards arguably now work

Donald Nordberg

donald@ nordberg.org.uk

1 Executive Business Centre, Bournemouth University, 89 Holdenhurst Road, Bournemouth BH8 8EB, UK 
harder than ever before. Disclosure rules give investors more information on the inner workings of the companies in which they invest. And waves of changes to voting arrangements have left investors more able to intervene when and even before things go wrong. And yet ....

During those 40 years, and especially during the last 25 , we have witnessed an intensification of the misdemeanors and malfeasance that initially prompted concern about the state of corporate governance. The problems have been widely attributed to neo-liberal economic thinking (Cioffi 2010; Cooper 2011) and a rise of financial capitalism (Davis 2008, 2010), which have increasingly informed how corporate boards work and the assumptions directors make. And despite intensive research and policy consultation processes, some scholars maintain "we still know very little about corporate governance" (Ahrens et al. 2011).

This article attempts to give a new shape to that lack of understanding. It examines the assumptions behind the key analyses and policy directions in corporate governance across two dimensions, accountability and cognition. It provides a framework for different themes in the literature that links to key, field-configuring events (Lampel and Meyer 2008; Oliver and Montgomery 2008) to the approaches to concerns that have arisen and evolved over those 40 years, to conceptualizations of cognition, and to the philosophical stances they imply. This analysis describes development from understandings rooted in rational-actor models associated with positivism, neo-classical economics and neo-liberal faith in markets; in the bounded rationality of in behavioral economics (Simon 1978); or notions of "reasonableness" (Toulmin 2001, 2003) and the pragmatism to which they point.

This framework helps, first, to categorize the literature and practices of corporate governance, drawing attention to the insights they offer and the blind spots they entail. Second, the evolution of theory and practice suggests a growing appreciation of the complexity of the field, which has confounded the search for solutions and which points to the need to approach further study from two different vantage points: a) empirically, the need to contain complexity by focusing attention on narrower understandings of the problem; and b) normatively, to avoid easy prescriptions and to encourage experimentation.

This paper is structured as follows. We look first at the historical context, including both market-related developments and institutional arrangements that applied during four periods of time when crises provoked concern and even outrage over the failings of directors and the failures of corporations that had wide and growing significance for society at large. We turn then to scholarly studies and policy approaches that have developed as a result of these crises.

This literature fits less than perfectly to the time periods in question, because ideas persist beyond the events that generated them and then influence future events. Nonetheless the themes in the literature link to the field-configuring events through sharing assumptions and developing a discourse about the nature of paths of accountability and the cognition of actors in the fields.

That points us towards distinctions that lead us ontologically from the simple to the complex, normatively from the positive to the pragmatic, and epistemologically from the rational to what Toulmin (2001) calls reasonableness. The paper then provides a discussion of the implications for future research and policy direction that might lead us away from ideal or even "best practice" approaches and toward a concept of "reasonably" good corporate governance. 


\section{Forty Years of Corporate Governance}

Concerns about what we now call corporate governance have roots in the writings by Adam Smith (1776/1904, 1759/1984) and the twentieth century elaboration by Adolf Berle and Gardiner Means (Berle 1931; Berle and Means 1932/1991). Both phases of attention arose from crises that endangered the system of production and society at large, though neither generated directly a field of study bringing together the complex interaction of corporations, investors, and more peripheral actors affected by the decisions they make.

That began to change, however, in the second half of the twentieth century, as renewed prosperity after the Second World War created growing savings that fueled the birth of collective investments. It happened first in the United States and then elsewhere, in particular through pensions and mutual funds. The articulation of modern portfolio theory (Markowitz 1952) and the efficient market hypothesis (Fama 1970) gave theoretical justification for these new market structures. The development and then growth of these institutional investors ameliorated the distance that Berle and Means (1932/1991) identified between corporate managers and individual investors, opening avenues for power to shift from the former to the latter, leading ultimately to what came to be called a market for corporate control (Manne 1965), later embodied in policy directions in many jurisdictions.

\section{Investor Power in the Early 1970s}

Following the go-go years of the 1960s (Brooks 1973), the US economy gave way in the early 1970s to the supposed economic impossibility of stagflation, when high inflation accompanied a long period of slow growth. Following a radical rise in oil prices, corporate earnings stagnated and with them the Dow Jones Industrial Average and wider stock market measures. Growing power of investors and poor corporate performance led to renewed concern about the problem identified in Berle and Means (1932/1991), but this time in a market and institutional context better able to address it. Jensen and Meckling (1976) articulated in theory the agency problem, which led to new market structures, incentives, and institutional measures - including enhanced financial disclosure, tougher audit requirements, and shareholder rights - to align executive behavior with shareholder interests.

With assumptions of a homo economicus (Rosenberg 1979), the almost-mechanical, selfservingly rational social actor, agency theory looked for mechanisms of corporate governance that might prevent self-interest from becoming uncontrolled. Among those mechanisms were: stock options, which provided an incentive that could direct the interests of directors toward shareholder needs; stronger voting rights, which gave shareholders the power to enforce those mechanisms; and transparency through cash flow statements and more granular profit and loss accounts, product and geographic reports, and clarity about categories of assets and liabilities, which reduced the information asymmetries that privileged insiders and impeded shareholders from using their power.

\section{Malfeasance in the Early 1990s}

In scholarship as well as in practice, the phenomenon of reckless, self-interested corporate executives was seen as largely a US-centric issue. But the early 1990s brought a string of corporate collapses in Britain, including Colorall, Polly Peck, the Bank of Credit and Commerce International, and two large listed companies controlled by Robert Maxwell. Together 
with memories of less dramatic problems including the 1977 Chiasso affair at Credit Suisse in Switzerland and those in the 1980s at IBH Holding and Schroeder Münchmeyer Hengst in West Germany, corporate governance problems no longer seemed confined to US practice.

Institutional change came in the form of the Cadbury Report and Code (1992) in the UK and parallel developments in many countries around the world, notably including France, Belgium, South Africa, and Australia, and new legislation on company law in Germany. These reforms sought many structural changes to boards of directors. In a recommendation widely copied elsewhere, Cadbury urged the separation of the roles of chairman and chief executive so that no one individual would have "unfettered power" in the boardroom. Others included new board committees to consider audit, nominations, and executive pay, and an emphasis on outside, non-executive directors, with the goal of heading off future crises by nipping excess in the bud. These largely structural changes limited the power of the chief executive with the aim of reducing agency problems (Nordberg and McNulty 2013). The emphasis on non-executives also highlighted concern about the independence of boards, a concern that would loom particularly large in seeking remedies that followed the next crisis.

\section{The Dot-com Bubble, Enron, WorldCom, Arthur Andersen, and ...}

The problems in the real economy proved too great for either the US solutions - with their focus on shareholder value and stock options to align the interests of managers with shareholders - or those elsewhere, with new powers given to boards and the non-executive directors. Using options to keep managers attuned to shareholder interests had perverse effects (Economist 2004; Matsumura and Yong 2005). Reform to board structures did not halt willful executives.

Early in 2000, scores of companies associated with the new economy of the internet collapsed, leading in some countries to the collapse of stock markets devoted to their new industrial revolution (Sell 2006; Audretsch and Lehmann 2008). But that was only a prelude to larger problems at some of the largest corporations.

Enron, an old-economy, oil-and-gas company, had moved into derivatives trading, became one of the world's most admired firms, and then failed spectacularly. Encouraged by its auditors, Arthur Andersen, it had made liberal use of illegal, off-balance-sheet accounting devices to inflate its market value, as well as stock options rewarding share-price performance to enrich its managers (Deakin and Konzelmann 2004; Nordberg 2008).

Other companies associated with Andersen soon unraveled as well. They included the telecommunications giant WorldCom, which suddenly arose, seemingly from nowhere, through the use of the market for corporate control and the powers given to corporate raiders under the mechanisms invented in the 1970s to "solve" the agency problem.

But this was not entirely a US phenomenon. Ahold of the Netherlands, Parmalat in Italy, and HIH Holdings in Australia all collapsed under allegations of false accounting or fraud. The policy response was new legislation - e.g. Sarbanes-Oxley Act (Library of Congress 2002) in the US and new codes of conduct like those of the German Cromme Commission (2002/2007) and the Higgs Review (Higgs 2003) in the UK. In the US, Nasdaq and the New York Stock Exchange adopted listing rules that echoed some of the provisions of Cadbury (Nordberg 2011).

As well as retaining many of the institutional arrangements of prior generations of corporate governance measures, these initiatives placed even greater emphasis on the independence and professionalism of the non-executive directors. They also concentrated more structural power in the board committees they controlled. Surely, this would prevent a recurrence of the problems of agency and managerial excess. 


\section{The Financial Crisis, 2007-09}

The early indications of the next crisis came in August 2007, when liquidity problems caused the near collapse of one French and two German banks that invested heavily in mortgagebacked securities and derivatives issued by US banks. Shortly thereafter, Northern Rock in the UK imploded, from largely home-grown causes. Early in 2008 the US investment bank Bear Stearns had to be rescued. Then, in September, Lehman Brothers wasn't rescued, setting off a chain reaction that brought the global banking industry and much of the insurance system perilously close to the brink.

The policy response was immediate but with some unexpected twists. In the US, the DoddFrank Act (Library of Congress 2010) heightened disclosure and investor scrutiny and gave further powers to large shareholders in the form of the ability to nominate directors and challenge management. From many other parts of the world came a policy drive for investor stewardship, that is, an emphasis on active ownership, focused on the long-term success of the companies in which they invest. These included an emphasis of the actions of investors through a Stewardship Code in the UK (FRC 2010b), similar initiatives in France, Germany, Italy, Japan, and elsewhere, and a revision to company law across the European Union (2016). This new direction suggested growing conviction that the "solution" to corporate governance problems might lie with shifting investor focus (Chiu 2012) and market structures (e.g. Kay 2012) to enhance long-term considerations, even as other voices were skeptical such measure would have the desired effects (Cheffins 2010; Reisberg 2015).

\section{Scholarly Studies and Policy Directions}

These four episodes, growing in intensity and social impact, point to failings in policy, to deficits in scholarly attention to the evaluation of the antecedents of corporate governance problems, and to perhaps to a lack of attention to nature of them. Ahrens et al. (2011) provide a critique of research that has failed to establish, for example, "specific ownership, board or incentive structures lead to better economic performance" or "conditions - e.g., firm size, industry, age - under which they generally lead to better results."

Economic performance modeling failed to anticipate the risks. Research on executive pay provided normative recommendations that exacerbated the problem. Research and policy pushed for greater board independence and professionalism, often at the cost of industry expertise and market knowledge.

Ahrens et al. (2011) go on to recommend refocusing research in several different directions: a) new measures of corporate performance, b) understanding the impact of large events, c) economic competence of key actors on boards and among investors, d) how governance is practiced, e) differing national contexts and institutional systems, and f) attention to the multiplicity of problematic agency relationships in the investment supply chain, not just in the shareholder-manager dyad. These approaches, however, concern largely operational issues in corporate governance rather than the underlying conceptual and philosophical premises upon which they rest.

Reading the literature against the timeline of critical incidents suggests another avenue of approach, which the balance of this article seeks to articulate. It is one that examines the assumptions behind the key analyses and policy directions that sought to explain the crises in corporate governance. These assumptions arise across two dimensions, accountability and 
Table 1 Periods and discourses of corporate governance

\begin{tabular}{|c|c|c|c|c|}
\hline Period of events & $1973-76$ & 1991-92 & $2001-03$ & $2007-10$ \\
\hline $\begin{array}{l}\text { Field-configuring } \\
\text { events }\end{array}$ & $\begin{array}{l}\text { Rise of mutual } \\
\text { funds; stagflation; } \\
\text { corporate } \\
\text { underperformance } \\
\text { esp. US }\end{array}$ & $\begin{array}{l}\text { Corporate failures, } \\
\text { esp. UK: } \\
\text { Maxwell, } \\
\text { BCCI, Colorall, } \\
\text { Polly Peck }\end{array}$ & $\begin{array}{l}\text { Corporate failures, } \\
\text { worldwide: e.g. } \\
\text { World Com, } \\
\text { Tyco; Parmalat; } \\
\text { HIH; dot-com } \\
\text { bubble }\end{array}$ & $\begin{array}{l}\text { Global financial crisis: } \\
\text { Lehman, Merrill } \\
\text { Lynch, AIG; } \\
\text { RBS, HBOS, } \\
\text { Northern } \\
\text { Rock; Fortis }\end{array}$ \\
\hline Discourse & $\begin{array}{l}\text { Market mechanisms } \\
\text { of corporate and } \\
\text { managerial control }\end{array}$ & Board structure & $\begin{array}{l}\text { Board independence } \\
\text { and } \\
\text { professionalism }\end{array}$ & $\begin{array}{l}\text { Board, investor } \\
\text { relationships }\end{array}$ \\
\hline Key documents & $\begin{array}{l}\text { Jensen and Meckling } \\
\text { (1976); Rappaport } \\
\text { (1981) }\end{array}$ & Cadbury (1992) & $\begin{array}{l}\text { Library of Congress } \\
\text { (2002); } \\
\text { Breeden (2003); } \\
\text { Higgs (2003) }\end{array}$ & $\begin{array}{l}\text { FRC }(2010 \mathrm{~b}) ; \\
\quad \text { European } \\
\text { Commission } \\
(2014)\end{array}$ \\
\hline
\end{tabular}

cognition, and are underpinned by philosophical stances that determine both their value and their shortcomings (see Table 1). We start with a discussion of the discourse that arose during and developed after each of these four periods of crisis.

\section{Discourses of Governance and Their Assumptions}

The groundbreaking analysis of Jensen and Meckling (1976) led to voluminous scholarly and commercial research to identify correlations between various variables of "good" governance (Agrawal and Knoeber 1996; Boyd 1995; Carpenter and Golden 1997; Dalton et al. 1998; Fama 1980; Gomez-Mejia et al. 1987). Indeed, the language of the scholarship and policy discussion alike invoked market mechanisms, prices, incentives, and other aspects that evoke neo-classical economics and suggests a mentality of governance ${ }^{1}$ steeped normatively in property rights and shareholder value maximization, empirically in emerging measurements of total shareholder return (Rappaport 1981, 1986), and not far beneath the surface in a faith that the efficiency of markets brought wisdom.

But the picture that emerged from empirical studies was nuanced. For example, Hermalin and Weisbach (1991) found that board composition moderated the effect of stock options on corporate performance. It suggested a less-than-automatic link between equity incentives and outcomes, thereby questioning the degree to which stock options can align managers' and shareholders' interests. Tosi et al. (2000) conducted a meta-analysis of executive pay and corporate performance that found the only $5 \%$ of the variation in pay in US companies was tied to performance.

In the crisis in the UK in early 1990s, the problems entailed by this discourse of market mechanisms were becoming apparent. In their analysis of the language changes in the main version of the UK code, Nordberg and McNulty (2013) identify in Cadbury (1992) an emphasis on language concerning structure: Good corporate governance, now seen as involving a) rationally minded division of labor through specialized committees

\footnotetext{
${ }^{1}$ The use of "mentalities of governance" here is a deliberate echo of "governmentality" in Foucault (2009), who explored the shift in understanding the nature of government as the Renaissance order gave way to acceptance of a rational, modernist rule of law in the Enlightenment, with the disruption of the Thirty-Years' War as a catalyst.
} 
and b) the separation of power in the boardroom, provided a "buttress" against the agency problem. But again, empirical studies raised doubts about whether this was too simple an approach for a complex problem. For example, a meta-review by Dalton et al. (1998) found only weak support for a link between two mechanisms of corporate governance (board composition and leadership structure; both advocated in the Cadbury reforms) and firm performance. Still the discourse of shareholder value supported by a structural approach to achieve good governance has persisted in financial-economic studies, legal arguments, and accounting-led analyses of the field.

By the time of the dot-com crisis and then Enron, skepticism about shareholder value was growing, however. Jensen (2001) had begun to invoke the concept of "enlightened value maximization," which, while rooted in the discourse of shareholder value, also opened a channel toward an instrumental form of stakeholder orientation. It provided a calculable rationale to consider interests beyond those of investors (cf. Letza et al. 2004).

The collapse of Enron brought a shift that created another layer in the discourse. That case (and the many others like it) illustrated the perverse effects of using options to align executive pay with investor interests. That case (and others like it) raised questions whether board structure and the remedies it prescribed were adequate (Aguilera et al. 2008; Arena and Braga-Alves 2013). This time new remedies led to a new discourse concerned with the need for board independence (Nordberg and McNulty 2013), a professional state of mind that policy mechanisms sought to embody through identifiable characteristics of directors. We see such a policy landscape in the US (Breeden 2003) and the UK (Higgs 2003), in outside, nonexecutive directors without commercial or personal ties to executives, and in having directors deemed independent control board processes concerning audit, nominations and pay.

There was in the literature already reason to be wary of expecting an easy solution from this version of a rationalist, positivist direction. Westphal (1998), for example, provided evidence that when facing greater board independence, CEOs engaged in higher levels of ingratiation and persuasion to neutralize the effects of the supposed stronger monitoring. The scholars who conducted qualitative research for the Higgs Review of the role of UK non-executive directors (McNulty et al. 2003), later raised doubts whether the mechanisms in Higgs (2003) would be adequate. They questioned whether understandings about monitoring and control based in agency theory or those about the service function of directors based in stewardship theory adequately reflected the complex lived experience of directors (Roberts et al. 2005).

Scholarship in corporate governance then added another layer of concern, opening a stream of work called "behavioral governance" (Gabrielsson and Huse 2004; Pye 2004; Charreaux 2005; Marnet 2005; van Ees et al. 2008). This literature studies the actions of directors and boards, cognizant of the limitations of a rationalist approach and drawing upon the concept of bounded rationality (Simon 1955) that informs behavioral economics.

With the financial crisis of 2007-09 and the resulting economic malaise came another turn in policy prescriptions and the search for good governance. The renamed UK Corporate Governance Code (FRC 2010a), drafted in the wake of the crisis, sought to develop a discourse about the need for strong relationships, within linked the boardroom and between boards and investors (Nordberg and McNulty 2013). The concurrent initiative of UK Stewardship Code (FRC 2010b) urged investors to become active owners, engaging in dialogue to develop mutual understanding (McNulty and Nordberg 2016). This approach chimed with literature describing governance based on relationships rather than mechanisms (Fairbrass and Zueva-Owens 2012; Goergen et al. 2010), and echoing themes in family-led governance (Ko and Liu 2016) and in other privately held firms (Uhlaner et al. 2007). 
The four phases of corporate governance problems, policies, and discourse are not entirely discrete in time or substance. Mechanisms feature in all of them, and agency concerns have not disappeared even as evidence has mounted of the limitations in its explanations of the work of boards, directors, and investors. Talk of market mechanisms in the early literature was not replaced by structural concerns post-Cadbury or the discourse of board independence postEnron. Indeed, examination of the version of the UK Corporate Governance Code as reformulated after the financial crisis shows each discourse layered upon the next (Nordberg and McNulty 2013).

These four, overlapping phases seem to be based on different understandings of accountability and different assumptions about director and investor cognition, which point toward different philosophical stances of what constitutes "good" governance, which creates a framework for understanding the literature and formulating research directions and informing policy.

In practice, decisions will not be guided solely by the goal of accountability and the process of cognition, of course. Emotions play a role in establishing preferences and work under the surface. An affective element lies behind the types of psychological ownership that employee stock options, for example, are meant to reinforce (Pierce et al. 1991). But the discourses of corporate governance, and the mechanisms of collective decision-making on boards and in institutional investment are designed to keep decisions on a rational footing. ${ }^{2}$ For those reasons let us focus, first, on accountability and then on cognition, as they appear in policy and the literature (see Table 2).

\section{Accountability}

Accountability looms large in the corporate governance literature and practice, though with contested meanings. Mulgan (2000) calls it an "ever-expanding" concept. Jensen and Meckling (1976) do not use the term directly but they speak about the "accounting reports" as a means for shareholders and creditors to monitor managers. In Cadbury (1992), the section heading is labeled "Accountability of Boards to Shareholders," making clear its understanding of the direction and inferring the purpose of accountability. Accountability here is collective (the board) and upwards, to investors, with the goal of shareholder value taken as understood.

Following the crises at Enron, WorldCom and others, the Sarbanes-Oxley Act (Library of Congress 2002) required CEOs and CFOs personally to attest to the accuracy of financial statements. The Breeden Report (Breeden 2003), however, emphasized the need for individual accountability of the CEO to the board as a mechanism to restore investor trust in corporations. The increased emphasis on director independence and professionalism points toward executive accountability not just hierarchically to shareholders, but also hierarchically within the board.

After the financial crisis, however, the new version of the UK Corporate Governance Code (FRC 2010a) discussed accountability only in rather general terms. It urged annual election of directors as a means of achieving accountability, but without directly mentioning shareholders in the section. Its title is simply "Accountability," leaving "shareholders" out. In the code's opening passages, accountability is a larger, less articulated concept, one of the principles of good governance. The accompanying UK Stewardship Code (FRC 2010b) uses the term only once, and in relation to the accountability of institutional investors to their beneficiaries.

\footnotetext{
${ }^{2}$ Such impediments to emotion may also impede the psychological ownership that seems to underpin investor stewardship. For a discussion, see McNulty and Nordberg (2016).
} 
Table 2 Discourses and accountability, cognition, and stance

\begin{tabular}{|c|c|c|c|c|}
\hline Discourse & Market mechanisms & Board structure & Board independence & $\begin{array}{l}\text { Board, investor } \\
\text { relationships }\end{array}$ \\
\hline Accountability & $\begin{array}{l}\text { Vertical-hierarchical; } \\
\text { shareholder value via } \\
\text { markets and external } \\
\text { monitoring }\end{array}$ & $\begin{array}{l}\text { Vertical-hierarchical; } \\
\text { shareholder value } \\
\text { via internal } \\
\text { monitoring }\end{array}$ & $\begin{array}{l}\text { Horizontal or } \\
\text { quasi-horizontal; } \\
\text { shareholder value via } \\
\text { internal control }\end{array}$ & $\begin{array}{l}\text { Relational } \\
\text { governance, } \\
\text { horizontal } \\
\text { and vertical }\end{array}$ \\
\hline Cognition & $\begin{array}{l}\text { Rational actors in efficient } \\
\text { markets }\end{array}$ & $\begin{array}{l}\text { Rational actors in } \\
\text { inefficient markets }\end{array}$ & Bounded rationality & Reasonableness \\
\hline $\begin{array}{l}\text { Ontological } \\
\text { and ethical } \\
\text { stance }\end{array}$ & Positivism; utility & Structuralism; utility & Idealism; duty & Pragmatism \\
\hline
\end{tabular}

This shift in the tone of policy documents suggests a growing acceptance that accountability is a more complex concept, as academic discussion had begun to reflect. Even before Cadbury, Roberts (1991) wrote of accountability as a multi-dimensional concept, elaborating it as having vertical ("individualizing") and horizontal ("socializing") dimensions (see also Roberts 2001). The former is impersonal and controlling, as the board monitors the CEO and shareholders the board. The latter, by contrast, is personal, face-to-face, and supporting. He argues that in corporate governance both are needed.

This view widens in the aftermath of Enron, in the suggestion that the lived experience of directors involves a complex dynamic between directors' control and service functions (Roberts et al. 2005), rather than the two discrete ones often cited in the corporate governance literature. It chimes with the views in Butler (2005) of accountability as a relational concept, in and Painter-Morland (2006) as one manifested both in boardrooms and between boards and other constituencies, and based not on mechanisms of control and sanction but instead on the human interaction of directors as moral agents.

This view takes the concept of accountability far from the idea that corporate disclosure to enable shareholder activism in the narrow form of episodic, change-seeking behavior (for a discussion, see McNulty and Nordberg 2016), and ultimately the market for corporate control. It also leads us to consider what cognitive assumptions underpin the four strands of thought in corporate governance practice and literature.

\section{Cognition}

The approach to corporate governance developed in Jensen and Meckling (1976) and the policy, research, and practice they engendered assumes corporate managers and directors are self-interested, rational actors, weighing up costs and benefits to themselves, homo economicus (Rosenberg 1979). Here the actor is the individual, not a collective agent. It was a perspective used to simplify economic models and one challenged from the outset and with new intensity following the financial crisis (Zafirovski 2014).

Rational choice coupled with notions of efficient markets, in which all relevant information is widely and freely available (Fama 1970), pointed toward a mechanistic approach to corporate governance. What was needed were institutional changes enabling investors to overcome the information asymmetries that prevent markets efficiently. They could then judge the value of corporations and through incentives align managers' self-interest with shareholders'. But the success of such prescriptions rests of those twin assumptions, each of which 
was challenged in the subsequent crises and in the emerging empirical and normative literature of boards, corporations, and investors.

Failures of the type that led to the Cadbury Code seemed to justify concern about the agency problem and its assumption of a rational, self-interested CEO. The remedies it prescribed therefore involve an assumption of rational cognition but based in a growing appreciation of the inefficiencies of markets.

Exemplified in the frantic efforts by Robert Maxwell to keep his companies afloat in the late 1980s, the all-powerful CEO could still hoodwink investors owing to information asymmetries. But in the case of Maxwell, the size of his personal shareholding meant his self-interest was well aligned with those of investors. The heart of the problem lay with his deceptive and perhaps criminal use of the pension funds of workers to prop up the share price to sustain debt covenants. These were risks addressed in legislation, not in the prescriptions of agency theory.

This points toward a second-level of market failure that points up how the complexity of investment markets prevents efforts at enhancing transparency from making markets efficient. In response, the structural remedies in Cadbury enhanced the governance function of boards, relying less on markets and more on the possibility of challenge in business decision-making. Cadbury's emphasis on separating the roles of chairman and CEO and emphasizing that of non-executives created an internal hierarchy that expands opportunities for what Forbes and Milliken (1999) call cognitive conflict within the boardroom.

Board structures put in place after Cadbury looked less than sufficient when the next crisis hit, however. Now attention focused on the limitations of cognition, the inability of directors to see and process all the available information and the inability of investors to monitor the performance of the companies in which they invested. This bounded rationality recalls the premises of behavioral economics, the limitations of rational choice theory, and the need for a change in the expectations of what directors can do (Marnet 2007).

The discourse of independence that developed after Enron sought greater diversity of views in the boardroom and hence cognitive conflict to accompany the structures that facilitated such discussions. Director independence and control of key board functions by independent directors provided not just internal monitoring but also the power to apply internal control.

This layering of market mechanisms, structures, and independence became the norm of "good" corporate governance in the years that followed. When the financial crisis struck, one response was moves to add more control, more mechanisms and structures of hierarchical accountability, and seek more independence on corporate boards. But another response came in acceptance of the limitations of both cognition and hierarchies of accountability as controls over the complexities, the interconnectedness of the issues facings boards and investors.

The preface to the UK Corporate Governance Code (FRC 2010a) written in response to the crisis claimed the code was "not a rigid set of rules" and urged that "boards must think deeply, thoroughly and on a continuing basis" with "mutual respect and openness" (FRC 2010a). "The Code has been enduring, but it is not immutable. Its fitness for purpose in a permanently changing economic and social business environment requires its evaluation at appropriate intervals" (FRC 2010a). These passages acknowledge, in a stronger tone than seen elsewhere in policy frameworks of corporate governance, the limitations of codes of conduct and of policy (Nordberg and McNulty 2013).

Moreover, the new UK code signaled appreciation that cognition was not merely bounded by the processing powers of the directors. That the environment is "permanently changing" and the code "not immutable" suggests that practitioners recognize mutability and contingency 
as inherent. This in turn suggests that directors look not for rational solutions and ideal corporate governance, but rather for a temporally bounded, contingent view of what is reasonable under the circumstances, and accept their may be reasonable doubt, as well.

\section{Philosophical Stances}

The narrow rationality of the early corporate governance prescriptions is a positivist argument grounded ethically in utility. There is a right way forward to a goal of shareholder value, one that could apply to all economic entities if only they weren't subject to the constraints on the mechanisms of free markets. ${ }^{3}$ As the discourse shifts from efficient markets to structure, the basis of the prescriptions becomes structural determinism, in which social structures, rather than individual agency, determine the path to utility. As the discourse shifts again from structure to independence, rationality yields to rationality-within-limits, and the weight of governance falls on the individual director. The director embodies an idealist view of good governance and an ethical stance based in principles of duty, to shareholders and the welfare of the company.

Less discussed and less well understood is notion of reasonableness and its implications for corporate governance policy and research. Following a brief recap on rational approaches and the origins of discomfort about their implications, we turn to discuss in greater depth the philosophical origins of this stance and then articulate a research agenda to develop its potential in interpreting corporate governance practice and in policy-making.

\section{Toward the Reasonable}

The notion of market efficiency developed in the 1950s assumed rational investors would, through the wisdom of markets, find the right price for assets, provided all relevant information was freely and widely available (Fama 1970). At the same time, however, doubts about rationality were emerging elsewhere in the literatures of economics and epistemology. Herbert Simon wrote of rationality as being bounded by our ability to compute the values at stake (Simon 1955, 1959); his insights led to a new field of behavioral economics.

Philosophers have long drawn a distinction between the rational and the reasonable. Rawls (2005) traces it to Kant's distinction in his Groundwork (1785/1964) between the categorical and hypothetical imperative. The former derives rationally at applies universally; the latter is reasoned but contingent on other circumstances. Linking the concept of the reasonable to his theory of justice as fairness (Rawls 1958, 1999), he argues that reasonableness involves a suspension of belief in comprehensive doctrines. Doing so makes possible the creation of liberal institutions, which accept freedom of action, rather than rule-based, structural solutions.

However, Sen (2009) contends that Rawls's political ideal, like his invocation of the "original position" in his theory of justice, nonetheless involves a transcendental stance, possible if not yet obtained. Sen questions whether it is possible "to identify 'just' institutions for a society without making them contingent upon actual behaviour" whether or not that behavior is just or reasonable (Sen 2009). That is, Rawls's reasonableness, like Simon's rationality, suggests striving toward an a priori truth.

\footnotetext{
${ }^{3}$ We see evidence of this in the rise of corporate governance ratings agencies being used not used as voting services for asset managers, but also in those investors' portfolio selection.
} 
The period in which Simon drew attention to bounded rationality and Rawls first articulated reasonableness in the context of justice saw other doubts about rationality emerge, though without positing an ideal condition. The philosopher Stephen Toulmin published the book The Uses of Argument in 1958 (republished 2003). In it he drew the distinction between the formal argument familiar in the abstract world of mathematics and what he called the substantive argumentation that constitutes discussion in the practical world of ordinary life.

Substantive argumentation involves a claim, supported by grounds, which are then linked by a warrant, that is, the logic or justification that leads us to accept the claim. This approach makes sense when the warrant itself is clear. Moreover, the more complex the field, the less likely that a claim and its associated warrant would be what Toulmin calls "field-invariant." With "field-dependent" ones, qualifications and counter-claims are possible, creating ambiguity in argumentation. ${ }^{4}$

The importance of field-dependent variables is not just that they limit the ability of people to determine what is rational. They make the argument contingent on circumstances, preventing actors from coming to a single, rationally derived rule. This argument was controversial at the time, running counter to mainstream analytic philosophy. But it resonated with many other thinkers, contributing to the sense of an inherent non-rationality arising in physics since Einstein and Heisenberg and evident in the sociology that came to be called postmodernism.

In Cosmopolis, Toulmin (1992) traced excessive faith in rationality in the modern era to Descartes and the resulting narrow conception of scientific inquiry that followed in the tradition he helped to establish. ${ }^{5}$ Returning to these themes in Return to Reason (2001), he argued that the best we could expect in an uncertain and contingent world was that people acted reasonably. It resonates with the contingency associated with the pragmatists Thomas Dewey and William James and is central to the work of Richard Rorty (1989).

Reasonableness is an important concept in law and business. Juries are asked to find evidence of guilt "beyond reasonable doubt." This view of reasonableness is often linked to the one Rawls articulated, namely that there is truth, but that it is difficult to identify with certainty. Here the need for reasonableness arises from an epistemological concern, though not an ontological one. Reasonableness is also evident for directors of corporations based in Delaware and other jurisdictions that have accepted its prevailing logic. The "business judgment" rule prevents shareholders for using hindsight to sue board members when a decision goes wrong (cf. Pearlstein 2014; Sharfman 2014). Denying hindsight as a justification acknowledges historical contingency. Insofar as business judgment involves acceptance of ontological uncertainty, it is more akin to Toulmin's view than Rawls's.

Among management theorists, Sandberg and Tsoukas (2011) invoke Toulmin's doubts about the rational in arguing for what they term "practical" rather than "scientific" rationality.

\footnotetext{
${ }^{4}$ An example may help clarify Toulmin's three aspects of argument: Ground: X was born in New York; Claim: X is a US citizen; Warrant: The US grants citizenship to all people born on US soil. Here, the warrant can arguably be accepted at face value; its logic does not vary by specific circumstances. Such warrants are sometimes left unspoken, understood by those concerned. But it does not consider the possibility that X has renounced US citizenship, illustrating the contingency. And warrants are also historically situated and may need to be qualified: Before a 1967 Supreme Court ruling (Afroyim v. Rusk, https://supreme.justia.com/cases/federal/us/387/253/case. html, people born on US soil might lose US nationality, for example by taking the nationality of their non-US parents.

5 Toulmin traces the problems of rationalism to Descartes, whose experiences during the Thirty-Years' War may ironically have provided strong emotional motivations to seek explanations that exclude emotion.
} 
Theirs is a view rooted in historically situated contingency and the rejection of the ideal, however remote.

Rationality, associated philosophically with positivism and certainty, falters at the hurdle of describing what happens in practice. Since Toulmin's early work, the analytic philosophy of the 1930 s to 1950 s has been in retreat and moral problems (he uses the example of medical practice) "are being handled less by strictly theoretical analysis than on a 'case-by-case' basis" (Toulmin 2001). In the face of complexity — of the sort of complexity that defies calculationmultiple answers may apply to the same situation, and what's best is impossible to determine.

Toulmin suggests the appeal of the rational arose from its formal, mathematical proof, which became compelling because its abstraction conveyed universality. The power of the proof lies in its formality, that is, its separation from the messiness of the world. Coping with that world, however, requires something else, what he calls "substantive arguments," which involve three distinctions from formal inquiries: first, that evidence from the real world is historical and therefore becomes dated; second, that rival interpretations of such data are possible; and third, that the concepts involved in interpretation can be ambiguous (Toulmin 2001).

The most substantive arguments can claim "is to put a conclusion 'beyond a reasonable doubt' and establish the 'strongest possible presumption'” (Toulmin 2001). These expressions are familiar in criminal law as well as the philosophical discussion that followed his Uses of Argument in the 1950s. This is not a relativist approach to determining the right thing to do. It is, rather, an argument based on contingency: In these circumstances, at this time, it is what reasonable people can agree.

\section{Contingency, Reasonableness and Trust}

The substantive arguments in corporate governance have changed over time. During four decades of debate over corporate governance, corporations and their executives and boards have sought to maintain discretion through invoking a managerialist warrant (i.e. managers know best because of informational advantages). Competing claims came first from a warrant of shareholder primacy, with roots in market mechanisms. This approach sought to expand disclosure of corporate information to reduce asymmetries; in extremis shareholders could invoke the market for corporate control, which underpins the warrant implicit in agency theory (i.e. that disclosure is expands the boundaries of rationality). When those claims falter after evidence of continued malpractice, a second attempt arises, based on structural reform and a warrant rooted in structuralism (i.e. structures determine behavior). When those claims falter, a warrant based in professionalism emerged (i.e. that agents - outside directors - with certain characteristics of independence will constrain managers).

Corporate governance actors thus make competing, substantive arguments over the value of one mechanism versus another based on differing claims, resting on different warrants but rooted in the same grounds: recurrent corporate failures. With each wave came attempts to codify the new, implied warrant, with each warrant layered upon the other. In Toulmin's terms, the mechanisms of governance shaped in the codes, practice and policy involve fielddependent understandings and field-dependent warrants to the competing claims, sometimes articulated, sometimes not. Moreover, they sought to do this in field-independent ways.

Following Toulmin's argument, rationality cannot deal with the uncertainties inherent in complex situations, those populated with field-dependent variables. In the case of corporate 
governance reform, when that third claim falters, a fourth warrant develops, based on reasonable people agreeing on how to respond to complex situations, in the knowledge that their judgment can at best be contingent. It makes the assumption that accountability of what Roberts $(2001,1991)$ calls the socializing variety will lead to understanding that accepts the contingency of decision, builds trust, and provides a route to think again.

\section{Some 'Reasonable’ Inferences for Further Research}

This analysis points to several reasonable inferences for policy and practice and a method to focus future research. If we accept that Toulmin's view applies in corporate governance, then attempts to find correlations, even causality between variables of governance and performance are likely to be frustrated in the effort to guide corporate decision processes.

Such relationships may, however, have predictive value at the level of the portfolio, and thus be of use to institutional investors, who monitor the performance of, say, 2000 companies to select a portfolio of, say, 500 investments. They are, however, much less likely to have predictive value at the level of individual boards and appointments of directors, where interpersonal relations and social complexity come into play. Worse, using such relationships as targets is likely to have perverse outcomes, through managing to targets rather than making reasonable arguments in reasoned debate (cf. O'Neill 2002).

Future research might therefore explore, at a practice level, how corporate decisions are made, especially in complex situations. It might examine in what way rational decision processes (e.g. calculations of net present value in an acquisition) are influenced by the uncertainties associated with considerations of other stakeholders, questions of the threat to corporate culture, or implications for the supply chain or value network of either the target firm or the acquirer. Theoretical research might consider how taking a real-options approach to strategic decisions deals with contingency and whether that could bring other lessons to seemingly simpler problems, such as identifying a new outside, non-executive director for the audit committee.

Policy-focused research might consider how better to tie regulation of corporate governance into the less formal, voluntary processes associated with codes of practice. Natural experiments already exist, for example in the differences between German and UK practice in the period since the German corporate governance code. The latter has a statutory framework but nonetheless mirrors provisions of the non-statutory, quasiself-regulatory UK code. The German code includes the UK language in its complyor-explain regime, which undercuts the power of statute. Might comply-or-explain itself be considered a "reasonable" compromise, giving boards discretion while also giving portfolio managers a tool to manage risk?

This article has also identified how interpretations of "good" governance has come to develop layers of argument about how to organize the work of boards of directors and their interactions with shareholders and others in the search for accountability. These layers arise from conflicting philosophical underpinnings, however, which may result in redundant or conflicting prescriptions. If we accept that reasonableness is an appropriate starting point, then research might seek to identify what constellations of mechanisms, processes, and practices provide reasonable substitutes for each other, rather than become additions to an everexpanding arsenal to protect corporate integrity. 
Some wider inferences are these: If we accept Toulmin's view, then in a variety of policy domains, macro-level associations - while useful for seeing the big picture - may be less valuable in prescribing micro-level decisions. The rules of the game embodied in field-level institutional arrangements may be handy short cuts in boundedly rational contexts, but they are less likely to provide guidance in complex or rapidly changing situations, where thoughtfulness is needed in application. And in a landscape of overlapping fields and competing institutions, openness to narrative and transparency during debate may be a better way to foster trust.

\section{Conclusions: Toward Reasonable Accountability?}

The history of corporate governance policy outlined in this article suggests that attempts to control through market mechanisms or board structures, rationally devised, may limit the freedom of action of those responsible for corporate excess without preventing excess itself. Boundedly rational appeals to independently minded directors may constrain access to industry- and company-specific knowledge, when definitions of independence exclude from a board those in a position to understand the firm's strategic issues. Such mechanisms may also threaten the discretion needed for experimentation, innovation and coping with the complexities that uncertainty entails.

In exercising "reasonable" oversight of the business, a board should be able to explain where, when, and why discretion is needed, and in what ways the standard formula doesn't fit. That is, directors should be able to provide a narrative of what matters and why. In explaining his discomfort with the modernist project of Descartes and later philosophers, Toulmin (2001) writes that the "reasonableness of narratives" came to be dismissed as a "soft-centered notion". Reasonableness is a middle way between the dichotomy of relativism and rationality.

Read normatively, Toulmin's reasonableness urges accountability, but not the accountability of perfect scores on a questionnaire. Instead it urges what Toulmin calls "substantive argumentation" in both corporate decision-making and public policy frameworks. Read from a practice perspective, reasonably good corporate governance involves the ability to look one's fellow directors in the eye and explain, or demand an explanation of, why this course of action is, somehow, best: best, that is, not of necessity, as in a mathematical proof, but, in Toulmin's terms, through substantive argumentation.

Reasonably good corporate governance would involve doing that in public as well, to shareholders and others, but also without pretending to have the formal proofs. This suggests that reasonable accountability is the ability to give a reasonable account, after thoughtful consideration and substantive argumentation, of one's decisions about an uncertain world.

\section{Compliance with Ethical Standards}

Conflict of Interest The author declares he has no conflicts of interest concerning this paper.

Open Access This article is distributed under the terms of the Creative Commons Attribution 4.0 International License (http://creativecommons.org/licenses/by/4.0/), which permits unrestricted use, distribution, and reproduction in any medium, provided you give appropriate credit to the original author(s) and the source, provide a link to the Creative Commons license, and indicate if changes were made. 


\section{References}

Agrawal, Anup, and Charles R. Knoeber. 1996. Firm Performance and Mechanisms to Control Agency Problems between Managers and Shareholders. The Journal of Financial and Quantitative Analysis 31 (3): 377-397. https://doi.org/10.2307/2331397.

Aguilera, Ruth V., Igor Filatotchev, Howard Gospel, and Gregory Jackson. 2008. An Organizational Approach to Comparative Corporate Governance: Costs, Contingencies, and Complementarities. Organization Science 19 (3): 475-492.

Ahrens, Thomas, Igor Filatotchev, and Steen Thomsen. 2011. The research frontier in corporate governance. Journal of Management and Governance 15 (3): 311-325.

Arena, Matteo P., and Marcus V. Braga-Alves. 2013. The discretionary effect of CEOs and board chairs on corporate governance structures. Journal of Empirical Finance 21 (0): 121-131. https://doi.org/10.1016/j. jempfin.2013.01.002.

Audretsch, David, and Erik Lehmann. 2008. The Neuer Markt as an institution of creation and destruction. International Entrepreneurship and Management Journal 4 (4): 419. https://doi.org/10.1007/s11365-0080085-0.

Berle, Adolf A., Jr. 1931. Corporate powers as powers in trust. Harvard Law Review 44 (7): 1049-1074.

Berle, Adolf A., Jr., and Gardiner C. Means. 1932/1991. The Modern Corporation and Private Property. Revised Aufl. New Brunswick: Transaction Publishers.

Boyd, Brian K. 1995. CEO duality and firm performance: a contingency model. Strategic Management Journal 16 (4): 301-312.

Breeden, R.C. . 2003. Restoring Trust: A Report on Corporate Governance for the Future of MCI, Inc. http://www.ecgi.org/codes/documents/breeden_cg_report.pdf. Accessed October 152006.

Brooks, John. 1973. The Go-Go Years: A Lively Exploration of That Incredible Era - The 1960's on Wall Street. New York: Weybright \& Talley.

Butler, Judith. 2005. Giving an Account of Oneself. New York: Fordham University Press.

Cadbury, Adrian. 1992. The Financial Aspects of Corporate Governance. http://www.ecgi. org/codes/documents/cadbury.pdf. Accessed 1 Sept 2015.

Carpenter, Mason A., and Brian R. Golden. 1997. Perceived managerial discretion: A study of cause and effect. Strategic Management Journal 18 (3): 187-206.

Charreaux, Gérard. 2005. Pour une gouvernance d'entreprise « comportementale » Une réflexion exploratoire.... (French); Toward a Behavioral Corporate Governance Theory. An Exploratory View.... (English). Revue Française de Gestion 31 (157): 215-238.

Cheffins, Brian R. 2010. The Stewardship Code's Achilles' Heel. Modern Law Review 73 (6): 1004-1025. https://doi.org/10.1111/j.1468-2230.2010.00828.x.

Chiu, Iris H.Y. 2012. Institutional shareholders as stewards: Toward a new conception of corporate governance. Brooklyn Journal of Corporate, Financial \& Commercial Law 6 (2): 387-432.

Cioffi, John W. 2010. Public Law and Private Power: Corporate Governance Reform in the Age of Finance Capitalism. Cornell Studies in Political Economy. Ithaca: Cornell University Press.

Cooper, Melinda. 2011. Complexity theory after the financial crisis: The death of neoliberalism or the triumph of Hayek? Journal of Cultural Economy 4 (4): 371-385. https://doi.org/10.1080/17530350.2011.609692.

Cromme Commission. 2002/2007. German Corporate Governance Code. http://www.corporate-governancecode.de. Accessed 20 June 2007.

Dalton, Dan R., Catherine M. Daily, Alan E. Ellstrand, and Jonathan L. Johnson. 1998. Meta-analytic reviews of board composition, leadership structure, and financial performance. Strategic Management Journal 19 (3): 269-290. https://doi.org/10.1002/(SICI)1097-0266(199803)19:3<269::AID-SMJ950>3.0.CO;2-K.

Davis, Gerald F. 2008. A new finance capitalism? Mutual funds and ownership re-concentration in the United States. European Management Review 5 (1): 11-21. https://doi.org/10.1057/emr.2008.4.

Davis, Gerald F. 2010. Is Shareholder Capitalism a Defunct Model for Financing Development? Review of Market Integration 2 (2-3): 317-331. https://doi.org/10.1177/097492921000200306.

Deakin, Simon, and Suzanne J. Konzelmann. 2004. Learning from Enron. Corporate Governance: An International Review 12 (2): 134-142.

Economist. 2004. Executive compensation: A better option. The Economist. Retrieved January 30, 2018, from http://www.economist.com/node/2601791.

Ees, van, Gerwin van der Laan Hans, and Theo J.B.M. Postma. 2008. Effective board behavior in The Netherlands. European Management Journal 26 (2): 84-93. https://doi.org/10.1016/j.emj.2008.01.002.

European Commission. 2014. Proposal for a Directive of the European Parliament and of the Council amending Directive 2007/36/EC as regards the encouragement of long-term shareholder engagement. European Commission legislative proposal. http://eur-lex.europa.eu/resource.html?uri=cellar:59fccf6c-c094-11e3-86 f9-01aa75ed71a1.0003.01/DOC_1\&format=PDF. Accessed 6 May 2015. 
European Union. 2016. Directive amending Shareholder Rights Directive 2007/36/EC, as agreed by European Parliament and Council. European Council and the Council of the European Union. http://data.consilium. europa.eu/doc/document/ST-15248-2016-INIT/en/pdf. Accessed 18 Jan 2017.

Fairbrass, Jenny, and Anna Zueva-Owens. 2012. Conceptualising Corporate Social Responsibility: 'Relational Governance' Assessed, Augmented, and Adapted. Journal of Business Ethics 105 (3): 321-335. https://doi. org/10.1007/s10551-011-0968-9.

Fama, Eugene F. 1970. Efficient Capital Markets: A Review of Theory and Empirical Work. Journal of Finance 25 (2): 383-417. https://doi.org/10.1111/j.1540-6261.1970.tb00518.x.

Fama, Eugene F. 1980. Agency Problems and the Theory of the Firm. Journal of Political Economy 88 (2): 288 307. https://doi.org/10.1086/260866.

Forbes, Daniel P., and Frances J. Milliken. 1999. Cognition and corporate governance: Understanding boards of directors as strategic decision-making groups. Academy of Management Review 24 (3): 489-505. https://doi. org/10.5465/AMR.1999.2202133.

Foucault, Michel. 2009. Security, Territory, Population: Lectures at the Collège de France, 1977-78. Trans. Graham Burchell. Basingstoke: Palgrave Macmillan.

FRC. 2010a. The UK Corporate Governance Code. UK Financial Reporting Council. http://www.frc.org. uk/documents/pagemanager/Corporate_Governance/UK\%20Corp\%20Gov\%20Code\%20June\%202010. pdf. Accessed 29 May 2010.

FRC. 2010b. The UK Stewardship Code. UK Financial Reporting Council. http://www.frc.org. uk/images/uploaded/documents/UK\%20Stewardship\%20Code\%20July\%2020103.pdf. Accessed 2 July 2010.

Gabrielsson, Jonas, and Morten Huse. 2004. Context, Behavior, and Evolution: Challenges in Research on Boards and Governance. International Studies of Management \& Organization 34 (2): 11-36.

Goergen, Marc, Christine Mallin, Eve Mitleton-Kelly, Ahmed Al-Hawamdeh, and Iris Hse-Yu Chiu. 2010. Corporate Governance and Complexity Theory. Cheltenham: Edward Elgar Publishing Ltd..

Gomez-Mejia, Luis R., Henry Tosi, and Timothy Hinkin. 1987. Managerial Control, Performance, and Executive Compensation. Academy of Management Journal 30 (1): 51-70. https://doi.org/10.2307 1255895 .

Hermalin, Benjamin E., and Michael S. Weisbach. 1991. The Effects of Board Composition and Direct Incentives on Firm Performance. FM: The Journal of the Financial Management Association 20 (4): $101-112$.

Higgs, Derek. 2003. Review of the Role and Effectiveness of Non-Executive Directors. http://www.ecgi. org/codes/documents/higgsreport.pdf. Accessed 15 Oct 2006.

Jensen, Michael C. 2001. Value maximization, stakeholder theory, and the corporate objective function. Journal of Applied Corporate Finance 14 (3): 8-21.

Jensen, Michael C., and William H. Meckling. 1976. Theory of the Firm: Managerial Behavior, Agency Costs and Ownership Structure. The Journal of Financial Economics 3 (4): 305-360. https://doi.org/10.1016 /0304-405X(76)90026-X.

Kant, Immanuel. 1785/1964. Groundwork of the Metaphysic of Morals. Trans. H.J. Paton. 3rd Aufl. New York: Harper Torchbooks.

Kay, John. 2012. The Kay review of UK equity markets and long-term decision making - Final report. Consultation of the UK Department of Business, Innovation and Skills. http://www.bis.gov. uk/assets/biscore/business-law/docs/k/12-917-kay-review-of-equity-markets-final-report.pdf. Accessed 23 July 2012.

Ko, Wai Wai, and Gordon Liu. 2016. A Typology of Guanxi-Based Governance Mechanisms for Knowledge Transfer in Business Networks of Chinese Small and Medium-Sized Enterprises. Group \& Organization Management Online First. https://doi.org/10.1177/1059601115627942.

Lampel, Joseph, and Alan D. Meyer. 2008. Guest Editors' Introduction: Field-Configuring Events as Structuring Mechanisms: How Conferences, Ceremonies, and Trade Shows Constitute New Technologies, Industries, and Markets. Journal of Management Studies 45 (6): 1025-1035. https://doi.org/10.1111/j.14676486.2008.00787.x.

Letza, Steve, Xiuping Sun, and James Kirkbride. 2004. Shareholding Versus Stakeholding: a critical review of corporate governance. Corporate Governance: An International Review 12 (3): 242-262. https://doi. org/10.1111/j.1467-8683.2004.00367.x.

Library of Congress. 2002. H.R.3763, The Sarbanes-Oxley Act. http://frwebgate.access.gpo.gov/cgi-bin/getdoc. cgi?dbname=107_cong_bills\&docid=f:h3763enr.txt.pdf. Accessed 15 Oct 2006.

Library of Congress. $\overline{2010}$. H.R.4173: Dodd-Frank Wall Street Reform and Consumer Protection Act US Library of Congress. http://thomas.loc.gov/cgi-bin/bdquery/z?d111:H.R.4173:. Accessed 20 Jan 2013.

Manne, Henry G. 1965. Mergers and the Market for Corporate Control. Journal of Political Economy 73 (2): 110-120. https://doi.org/10.2307/1829527. 
Markowitz, Harry. 1952. Portfolio Selection. The Journal of Finance 7 (1): 77-91. https://doi.org/10.2307 $/ 2975974$.

Marnet, Oliver. 2005. Behavior and Rationality in Corporate Governance. Journal of Economic Issues 39 (3): 613-632.

Marnet, Oliver. 2007. History repeats itself: The failure of rational choice models in corporate governance. Critical Perspectives on Accounting 18 (2): 191-210. https://doi.org/10.1016/j.cpa.2005.11.010.

Matsumura, Ella Mae, and Shin Jae Yong. 2005. Corporate Governance Reform and CEO Compensation: Intended and Unintended Consequences. Journal of Business Ethics 62 (2): 101-113. https://doi. org/10.1007/s10551-005-0175-7.

McNulty, Terry, and Donald Nordberg. 2016. Ownership, Activism and Engagement: Institutional Investors as Active Owners. Corporate Governance: An International Review 24 (3): 346-358. https://doi.org/10.1111 /corg. 12143.

McNulty, Terry, John Roberts, and Philip Stiles. 2003. Creating accountability within the board: The work of the effective non-executive director. A report for the Review of the Role and Effectiveness of the Non-Executive Director conducted by Mr Derek Higgs. http://webarchive.nationalarchives.gov.uk/tna/+/http://www.dti.gov. uk/cld/non_exec_review/pdfs/stilesreport.pdf/. Accessed 21 Aug 2010.

Mulgan, Richard. 2000. 'Accountability': An ever-expanding concept? Public Administration 78 (3): 555-573.

Nordberg, Donald. 2008. Waste Makes Haste: Sarbanes-Oxley, Competitiveness and the Subprime Crisis. Journal of Financial Regulation and Compliance 16 (4): 365-383. https://doi.org/10.1108 /13581980810918422.

Nordberg, Donald. 2011. Corporate Governance: Principles and Issues. London: Sage.

Nordberg, Donald, and Terry McNulty. 2013. Creating better boards through codification: Possibilities and limitations in UK corporate governance, 1992-2010. Business History 55 (3): 348-374. https://doi. org/10.1080/00076791.2012.712964.

Oliver, Amalya L., and Kathleen Montgomery. 2008. Using Field-Configuring Events for Sense-Making: A Cognitive Network Approach. Journal of Management Studies 45 (6): 1147-1167. https://doi.org/10.1111 j.1467-6486.2008.00786.x.

O'Neill, Onora. 2002. Lecture 3: Called to Account. Reith Lectures, BBC. http://www.bbc.co.uk/radio4 /reith2002/lecture3.shtml Accessed 30 July 2010.

Painter-Morland, Mollie. 2006. Redefining Accountability As Relational Responsiveness. Journal of Business Ethics 66 (1): 89-98.

Pearlstein, Steven. 2014. Social Capital, Corporate Purpose and the Revival of American Capitalism. Center for Effective Public Management at Brookings. http://www.brookings.edu/ /media/research/files/papers/2014 $/ 01 / 10 \% 20$ social\%20capital\%20corporate\%20purpose\%20pearlstein/brookingspearlsteinv5_revised $\% 20$ feb\%202014.pdf. Accessed 22 Feb 2014.

Pierce, Jon L., Stephen A. Rubenfeld, and Susan Morgan. 1991. Employee ownership: A conceptual model of process and effects. Academy of Management Review 16 (1): 121-144. https://doi.org/10.5465 /amr.1991.4279000.

Pye, Annie. 2004. The Importance of Context and Time for Understanding Board Behavior. International Studies of Management \& Organization 34 (2): 63-89.

Rappaport, Alfred. 1981. Selecting strategies that create shareholder value. Harvard Business Review 59 (3): 139-149.

Rappaport, Alfred. 1986. Creating shareholder value: The new standard for business performance. New York: Free Press.

Rawls, John. 1958. Justice as Fairness. The Philosophical Review 67 (2): 164-194. https://doi.org/10.2307 $/ 2182612$.

Rawls, John. 1999. A Theory of Justice. Revised Aufl. Cambridge: Belknapp Press.

Rawls, John. 2005. Political Liberalism. Expanded Aufl. New York: Columbia University Press.

Reisberg, Arad. 2015. The UK Stewardship Code: On the road to nowhere? Journal of Corporate Law Studies 15 (2): 217-253. https://doi.org/10.1080/14735970.2015.1044771.

Roberts, John. 1991. The possibilities of accountability. Accounting, Organizations and Society 16 (4): $355-368$.

Roberts, John. 2001. Trust and Control in Anglo-American Systems of Corporate Governance: The Individualizing and Socializing Effects of Processes of Accountability. Human Relations; Studies Towards the Integration of the Social Sciences 54 (12): 1547-1572. https://doi.org/10.1177/00187267015412001.

Roberts, John, Terry McNulty, and Philip Stiles. 2005. Beyond Agency Conceptions of the Work of the NonExecutive Director: Creating Accountability in the Boardroom. British Journal of Management 16 (S1): S5S26.

Rorty, Richard. 1989. Contingency, Irony, and Solidarity. Cambridge: Cambridge University Press.

Rosenberg, Alexander. 1979. Review Symposium: Can Economic Theory Explain Everything? Philosophy of the Social Sciences 9 (4): 509-529. https://doi.org/10.1177/004839317900900409. 
Sandberg, Jürgen, and Haridimos Tsoukas. 2011. Grasping the logic of practice: Theorizing through practical rationality. Academy of Management Review 36 (2): 338-360.

Sell, John W. 2006. The Neuer Markt is Dead. Long Live the Neuer Markt! International Advances in Economic Research 12 (2): 191. https://doi.org/10.1007/s11294-006-9003-9.

Sen, Amartya. 2009. The Idea of Justice. London: Penguin.

Sharfman, Bernard S. 2014. Shareholder Wealth Maximization and its Implementation under Corporate Law. Florida Law Review 66 (1): 389-432.

Simon, Herbert A. 1955. A Behavioral Model of Rational Choice. Quarterly Journal of Economics 69 (2): 99 118. https://doi.org/10.2307/1884852.

Simon, Herbert A. 1959. Theories of Decision-Making in Economics and Behavioral Science. American Economic Review 49 (3): 253-283.

Simon, Herbert A. 1978. Rationality as Process and Product of Thought. American Economic Review 68 (2): 4. Smith, Adam. 1759/1984. The Theory of Moral Sentiments. Indianapolis: Liberty Fund.

Smith, Adam. 1776/1904. The Wealth of Nations. London: Methuen \& Co..

Tosi, Henry L., Steve Werner, Jeffrey P. Katz, and Luis R. Gomez-Mejia. 2000. How Much Does Performance Matter? A Meta-Analysis of CEO Pay Studies. Journal of Management 26 (2): 301-339.

Toulmin, Stephen. 1992. Cosmopolis: Hidden Agenda of Modernity. Chicago: University of Chicago Press.

Toulmin, Stephen. 2001. Return to Reason. Cambridge: Harvard University Press.

Toulmin, Stephen. 2003. The Uses of Argument. Updated Aufl. Cambridge: Cambridge University Press.

Uhlaner, Lorraine, Roberto Floren, and Jurgen Geerlings. 2007. Owner Commitment and Relational Governance in the Privately-Held Firm: An Empirical Study. Small Business Economics 29 (3): 275-293. https://oi. org/10.1007/s11187-006-9009-y.

Westphal, James D. 1998. Board Games: How CEOs Adapt to Increases in Structural Board Independence from Management. Administrative Science Quarterly 43 (3): 511-537.

Zafirovski, Milan. 2014. Rational Choice Requiem: The Decline of an Economic Paradigm and its Implications for Sociology. American Sociologist 45 (4): 432-452. https://doi.org/10.1007/s12108-014-9230-0.

Donald Nordberg is Associate Professor of strategy and corporate governance at Bournemouth University Business School. His research has been published in Corporate Governance: An International Review, Business History; Business Ethics: A European Review; Journal of General Management; Journal of Financial Regulation \& Compliance; Journalism: Theory, Practice \& Criticism; Review of Political Economy and other journals. He has also contributed chapters to several books and is author of Corporate Governance: Principles \& Issues (Sage: 2011). He was educated at Reed College in Portland, Oregon, the University of Illinois at Urbana-Champaign, Warwick Business School and the University of Liverpool Management School. 